\title{
Synthesis, in silico Study and Antileishmanial Evaluation of New Selenides Derived from 7-Chloro-quinoline and $N$-Phenylacetamides
}

\author{
Min-Fu N. Huang, ${ }^{a}$ José A. S. Luis, ${ }^{\circ b}$ Alison P. da Silva, Juliana C. Rocha, ${ }^{c}$ \\ Tatjana K. S. Lima, ${ }^{c}$ Marcus T. Scotti, ${ }^{\oplus d}$ Luciana Scotti, ${ }^{d}$ Rafael F. de Oliveira, ${ }^{\circledR a}$ \\ Helivaldo D. S. Souza, ${ }^{\circledR a}$ Petrônio F. de Athayde-Filho ${ }^{a}$ and José M. Barbosa-Filho ${ }^{\circledR *, d}$ \\ a Departamento de Química, Universidade Federal da Paraíba, 58051-900 João Pessoa-PB, Brazil \\ ${ }^{b}$ Centro de Educação e Saúde, Universidade Federal de Campina Grande, 58175-000 Cuité-PB, Brazil \\ 'Departamento de Biologia Molecular e Celular, Universidade Federal da Paraíba, 58051-900 João Pessoa-PB, Brazil \\ dPrograma de Pós-Graduação em Produtos Naturais e Sintéticos Bioativos, Universidade Federal da Paraíba, \\ 58051-900 João Pessoa-PB, Brazil
}

\begin{abstract}
This study describes a virtual screening performed for two series of selenides ( 28 compounds), derived from $\mathrm{N}$-phenylacetamides chlorides and 7-chloro-quinoline, to determine their potential for leishmanicidal activity against Leishmania amazonensis and Leishmania donovani. Seven compounds were predicted as potential leishmanicides; therefore, they were synthesized from elemental selenium, as a precursor for the production of NaHSe, and subsequent reactions with 4,7-dichloro-quinoline and $\mathrm{N}$-phenylacetamides chlorides were performed. The compounds were characterized by infrared (IR), ${ }^{1} \mathrm{H}$ and ${ }^{13} \mathrm{C}$ nuclear magnetic resonance (NMR), and sent for in vitro cytotoxicity tests against $L$. amazonensis and were found to be active and selective, and two compounds presented half-maximal inhibitory concentrations $\left(\mathrm{IC}_{50}\right)$ of 5.67 and $10.81 \mu \mathrm{g} \mathrm{mL}^{-1}$. They also presented good interaction energies in the docking study, suggesting that may exert their effects by inhibiting the $N$-myristoyltransferase and $O$-acetylserine sulfhydrylase enzymes in parasites.
\end{abstract}

Keywords: selenium, selenide, virtual screening, anti-leishmanial, molecular docking

\section{Introduction}

Leishmaniasis is considered to be a neglected disease, caused by the intracellular invasion of protozoans belonging to the Leishmania genus, which are transmitted by sandfly bites. Leishmaniasis is considered to be an endemic disease in 98 countries, with more than 350 million people at risk. ${ }^{1-3}$ The development of new drugs represents a major challenge for medicinal chemistry, with the aim of identifying more efficient and less toxic drugs than those that are currently used (pentavalent antimonials and amphotericin B). Recent research has suggested that organic selenium-based compounds may play a fundamental role in combating this parasitosis, in addition to other parasitic diseases, such as malaria and yellow fever. ${ }^{4-8}$ These studies postulate that selenic compounds may represent starting points for the design of new drugs to treat Leishmania infections.

*e-mail: jbarbosa@ltf.ufpb.br
The medications that are currently available for the treatment of visceral leishmaniasis (VL) and cutaneous leishmaniasis (CL) include antimonial drugs (SbV), amphotericin B (AMB), and miltefosine (MIL), which all display high levels of toxicity and/or require long-lasting treatment regimens. ${ }^{9}$ In addition, except for AMB, these drugs must be administered parenterally. ${ }^{10}$ In the last decade, resistance to SbV has increased, primarily due to low rates of compliance with the treatment schedule. In areas where parasites have become resistant to $\mathrm{SbV}, \mathrm{AMB}$ is commonly used because it is more active; however, AMB treatment requires a month of hospitalization to monitor kidney function. MIL is highly active for the treatment of VL and has good tolerance, but its potential teratogenicity remains a risk. In addition, these drugs are costly. Therefore, research has sought to identify new treatments for leishmaniasis that are safer, cheaper, and easier to administer than the currently available drugs.

Recently, enzymes involved in the prevention of oxidative damage have been reported as interesting targets 
for new antileishmanial drugs. ${ }^{11}$ Substances with antienzymatic activities, such as organoselenic compounds, have been considered of particular importance. ${ }^{12}$ Some anti-cancer drugs, with anti-proliferative activities, have also been shown to be effective for combating protozoa, and several selenium compounds have also been found to display potent anticancer activities. Thus, active compounds against leishmaniasis may exist among current antitumor drugs. ${ }^{13}$ Our research group has performed several studies $^{7,8,14}$ that have been successful in identifying new candidates for antileishmanial drug development, with the assistance of computational tools to advance the screening process. This study aimed to perform a virtual screen (using both ligand-based and structure-based methodologies) on two series of selenide-derived compounds (one series containing derivatives of 7-amino-quinoline and another series containing derivatives of $N$-phenylacetamides chlorides). Based on the screening results, the compounds that were considered most likely to be active were synthesized. After their structures were determined using conventional methods, the synthesized compounds were subjected to in vitro tests against Leishmania amazonensis cells, to verify their antileishmanial potential.

\section{Results and Discussion}

In silico study

\section{Ligand-based approach}

Our research group has previously and successfully used a virtual screening (VS) methodology for the selection of molecules with potential leishmanicidal activity. ${ }^{7,8}$ The methodology uses a combination of ligand-based (LB) and structure-based (SB) tools, which are based on the ligand and receptor structures, respectively. The selenide banks $\mathbf{4 a - 4 n}$ and $\mathbf{7 a - 7 n}$ (Scheme 1) were screened, using our VS model, which compares the structures of the new molecules against databases containing 722 molecules with known activity against promastigote forms of L. amazonensis and 818 molecules with known activity against promastigote forms of $L$. donovani. For each molecule, 128 molecular descriptors were calculated using the Volsurf program ( $\mathrm{v}$ 1.0.7), ${ }^{15}$ which were then transferred to the Konstanz Information Miner (KNIME) program (v. 3.4.0) ${ }^{16}$ to build a random forest (RF) prediction model. ${ }^{7,8}$ Then, the probabilities of activity against L. amazonensis and L. donovani were calculated for each compound in $\mathbf{4 a - 4 n}$ and $\mathbf{7 a - 7 n}$, and the results are shown in Table 1. Compounds $\mathbf{4 f}, \mathbf{4 g}, \mathbf{4 h}, \mathbf{4 l}, \mathbf{4 m}, \mathbf{7 j}$, and $\mathbf{7 n}$ were predicted as being active (A), indicating a probability (p) of activity above $50 \%$ against at least one Leishmania species. These molecules were selected for synthesis, and the synthesized molecules were sent for in vitro testing against L. amazonensis, which was the species available in our laboratory and is one of the most prevalent species in Brazil. ${ }^{17}$

\section{Docking study}

Following the combined approach, a molecular docking study (SB) was performed comparing the L. donovani enzymes topoisomerase I, $N$-myristoyltransferase (NMT), cyclophilin, and $O$-acetylserine sulfhydrylase (OASS),<smiles>[R]c1ccc(NC(=O)CC(C)Cl)cc1</smiles>

(ii)<smiles>[R]c1ccc(NC(=O)CC(C)(C)[Se][Te]C(C)(C)CC(=O)Nc2ccc([R])cc2)cc1</smiles>

$(4 a-4 n)$

\begin{tabular}{l|llll} 
& \multicolumn{5}{|c}{$\mathrm{n}$} \\
$\mathrm{R}$ & $\mathbf{1}$ & $\mathbf{2}$ & $\mathbf{1}$ & $\mathbf{2}$ \\
\hline $\mathrm{H}$ & $\mathbf{4 a}$ & $\mathbf{4 h}$ & $\mathbf{7 a}$ & $\mathbf{7 h}$ \\
$\mathrm{Me}$ & $\mathbf{4 b}$ & $\mathbf{4 i}$ & $\mathbf{7 b}$ & $\mathbf{7 i}$ \\
$\mathrm{Et}$ & $\mathbf{4 c}$ & $\mathbf{4 j}$ & $\mathbf{7 c}$ & $\mathbf{7 j}$ \\
$\mathrm{Cl}$ & $\mathbf{4 d}$ & $\mathbf{4 k}$ & $\mathbf{7 d}$ & $\mathbf{7 k}$ \\
$\mathrm{Br}$ & $\mathbf{4 e}$ & $\mathbf{4 l}$ & $\mathbf{7 e}$ & $\mathbf{7 I}$ \\
$\mathrm{OMe}$ & $\mathbf{4 f}$ & $\mathbf{4 m}$ & $\mathbf{7 f}$ & $\mathbf{7 m}$ \\
$\mathrm{NO}_{2}$ & $\mathbf{4 g}$ & $\mathbf{4 n}$ & $\mathbf{7 g}$ & $\mathbf{7 n}$
\end{tabular}

(1)

(2)

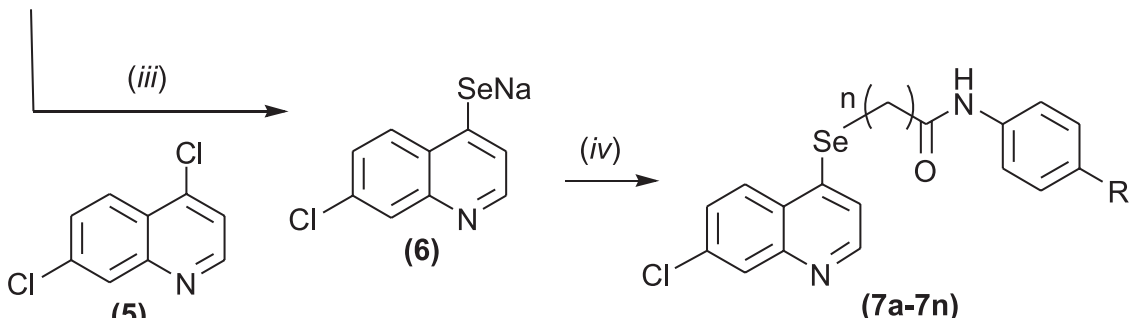

(5)

Scheme 1. Structures of the molecules used in the virtual screening and the synthetic route used to obtain target molecules. Reagents and conditions: (i) EtOH, $\mathrm{NaBH}_{4}$, room temperature (rt), $5 \mathrm{~min}, 26^{\circ} \mathrm{C}$; (ii) dimethylformamide (DMF), $N$-phenylacetamides chlorides, $26{ }^{\circ} \mathrm{C}, 4-6 \mathrm{~h}, 80 \%$; $($ iii) $\mathrm{DMF}$, 4,7-dichloroquinoline, rt, 30 min; (iv) DMF, $N$-phenylacetamides chlorides, rt, 8 h, 38-75\%. 
Table 1. Prediction of activity, with their respective probabilities (p), which were calculated using the RF model for compounds $4 \mathbf{a}-\mathbf{4 n}$ and $\mathbf{7 a - 7 n}$ against L. donovani and L. amazonensis, and the results of the in vitro tests against the promastigote forms of L. amazonensis

\begin{tabular}{|c|c|c|c|c|c|c|c|}
\hline \multirow{2}{*}{ Compound } & \multicolumn{2}{|c|}{ L. donovani } & \multicolumn{2}{|c|}{ L. amazonensis } & \multirow{2}{*}{$\begin{array}{l}\text { In vitro results for } \\
\text { L. amazonensis } \mathrm{IC}_{50} \pm \mathrm{sd} / \\
\left.(\mu \mathrm{g} \mathrm{mL})^{-1}\right)\end{array}$} & \multirow{2}{*}{$\begin{array}{l}\text { In vitro results for } \\
\text { PBMC } \mathrm{IC}_{50} \pm \mathrm{sd} / \\
\quad\left(\mu \mathrm{gL}^{-1}\right)\end{array}$} & \multirow[b]{2}{*}{ SI } \\
\hline & Activity & $\mathrm{p}$ & Activity & $\mathrm{p}$ & & & \\
\hline $4 a$ & I & 0.33 & I & 0.26 & & & \\
\hline $4 b$ & I & 0.37 & I & 0.27 & & & \\
\hline $4 c$ & I & 0.39 & I & 0.31 & & & \\
\hline $4 d$ & I & 0.39 & I & 0.37 & & & \\
\hline $4 e$ & I & 0.37 & I & 0.33 & & & \\
\hline $4 f$ & I & 0.49 & A & 0.59 & $36.61 \pm 0.98$ & $>400$ & $>10.9$ \\
\hline $4 \mathrm{~g}$ & A & 0.54 & A & 0.61 & $10.81 \pm 0.01$ & $>400$ & $>37.0$ \\
\hline $4 h$ & I & 0.47 & $\mathrm{~A}$ & 0.55 & $221.6 \pm 11.6$ & $>400$ & $>1.8$ \\
\hline $4 i$ & I & 0.34 & I & 0.39 & & & \\
\hline $4 j$ & I & 0.48 & I & 0.38 & & & \\
\hline $4 k$ & I & 0.39 & I & 0.43 & & & \\
\hline 41 & A & 0.53 & I & 0.40 & $100.5 \pm 5.26$ & $>400$ & $>3.9$ \\
\hline $4 m$ & I & 0.48 & A & 0.58 & $21.05 \pm 6.29$ & $>400$ & $>19.0$ \\
\hline $4 n$ & I & 0.34 & I & 0.49 & & & \\
\hline $7 \mathbf{a}$ & I & 0.30 & I & 0.39 & & & \\
\hline $7 b$ & I & 0.41 & I & 0.39 & & & \\
\hline $7 \mathrm{c}$ & I & 0.47 & I & 0.40 & & & \\
\hline $7 d$ & I & 0.45 & I & 0.41 & & & \\
\hline $7 e$ & I & 0.45 & I & 0.37 & & & \\
\hline $7 f$ & I & 0.45 & I & 0.45 & & & \\
\hline $7 \mathrm{~g}$ & I & 0.42 & I & 0.43 & & & \\
\hline $7 \mathrm{~h}$ & I & 0.15 & I & 0.17 & & & \\
\hline $7 \mathbf{i}$ & I & 0.17 & I & 0.06 & & & \\
\hline $7 \mathbf{j}$ & I & 0.50 & A & 0.64 & $71.49 \pm 5.89$ & $>400$ & $>5.6$ \\
\hline $7 k$ & I & 0.25 & I & 0.24 & & & \\
\hline 71 & I & 0.22 & I & 0.19 & & & \\
\hline $7 m$ & I & 0.36 & I & 0.49 & & & \\
\hline $7 n$ & A & 0.57 & A & 0.69 & $5.67 \pm 0.07$ & $>400$ & $>70.5$ \\
\hline
\end{tabular}

$\mathrm{IC}_{50}$ : half-maximal inhibitory concentrations; sd: standard deviation; PBMC: peripheral blood mononuclear cells; A: active; I: inactive; SI: selectivity index.

which are available at the Protein Data Bank (PDB), with the entire selenide bank, because the isoforms of these enzymes are expressed by Leishmania species and are not in humans, so molecules selective for these targets can be selective for these pathogens and have a lower probability of causing side effects. The combined approach uses the data from the LB study and the data from the SB study in the same formula, refining the probabilities that a molecule is active against a specific target. ${ }^{7,8}$ The data for the enzymes used, the interaction energies, and the results of the combined approach are described in Tables S1 and S2 (Supplementary Information section), and Table 2, respectively.

Table S2 (Supplementary Information section) shows that compounds $\mathbf{4 g}$ and $\mathbf{7 n}$ had the lowest interaction
Table 2. The activities of the selenoderivatives with the best performances in the docking study, for each enzyme. $p_{c}$ indicates the probability of activity from the combined approach

\begin{tabular}{lcccc}
\hline \multirow{2}{*}{ Compound } & \multicolumn{4}{c}{ Combined probabilities $\left(\mathrm{p}_{\mathrm{c}}\right)$} \\
\cline { 2 - 5 } & TOPI & NMT & Cyp & OASS \\
\hline $\mathbf{4 f}$ & 0.57 & 0.61 & 0.54 & 0.63 \\
$\mathbf{4 g}$ & 0.58 & 0.64 & 0.55 & 0.69 \\
$\mathbf{4 h}$ & 0.52 & 0.55 & 0.50 & 0.58 \\
$\mathbf{4}$ & 0.52 & 0.63 & 0.51 & 0.60 \\
$\mathbf{4 m}$ & 0.54 & 0.61 & 0.53 & 0.64 \\
$\mathbf{7 j}$ & 0.57 & 0.62 & 0.55 & 0.68 \\
$\mathbf{7 n}$ & 0.59 & 0.69 & 0.59 & 0.70 \\
\hline
\end{tabular}

TOPI: topoisomerase I; NMT: $N$-myristoyltransferase; Cyp: cyclophilin; OASS: $O$-acetylserine sulfhydrylase. 
energies for the enzymes used in our docking study. The most favorable interactions were identified between these two compounds and the NMT and OASS enzymes. These results corroborated the results of the in vitro study, in which compounds $\mathbf{7 n}$ and $\mathbf{4 g}$ were found to have the lowest half-maximal minimum inhibitory concentrations $\left(\mathrm{IC}_{50}\right)$ for these enzymes (Table 1), suggesting that these compounds may be able to exert leishmanicidal activity by inhibiting these enzymes; however, additional studies remain necessary to clearly elucidate the mechanism of action. Figure 1 also shows the lowest energy dock positions for compounds $\mathbf{4 g}$ and $\mathbf{7 n}$ with the enzymes NMT and OASS, highlighting the primary interactions with the hydrogen in the active site of the enzymes. Figure 1 also shows that $\mathbf{4 g}$ and $\mathbf{7 n}$ present similar modes of interaction with the NMT enzyme, as the $\mathrm{NO}_{2}$ groups in both molecules interact with the amino acid residues Asn383 and Val378, and the $\mathrm{N}$ of their acetamide groups interact with the residue Tyr326. For OASS, no similar patterns of interaction were observed between the two compounds; the $\mathrm{NO}_{2}$ group of $\mathbf{4 g}$ interacts with the residues Tyr307 (A), Ser302 (A), Ser274 (A), Gly184 (A), and Asn278 (A), whereas the $\mathrm{NO}_{2}$ group of compound 7n, interacts with Thr187 (A) and Thr190 (A), and the carbonyl $\mathrm{O}$ interacts with the Ser86 residue (A).
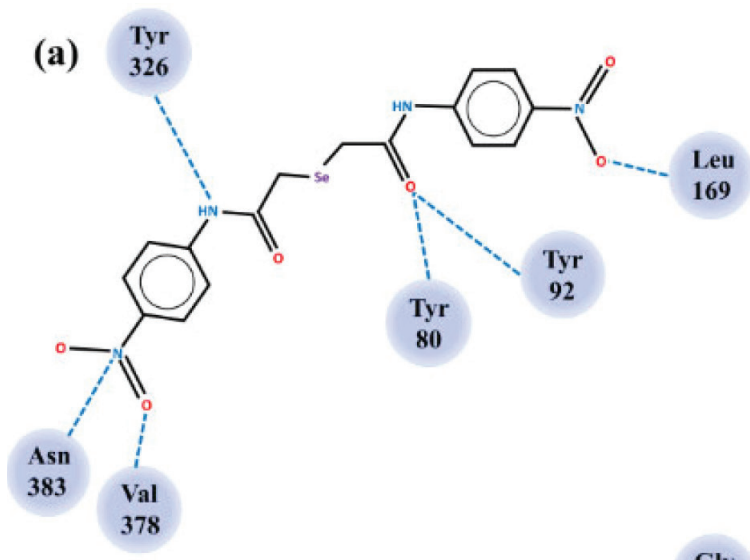

(c)

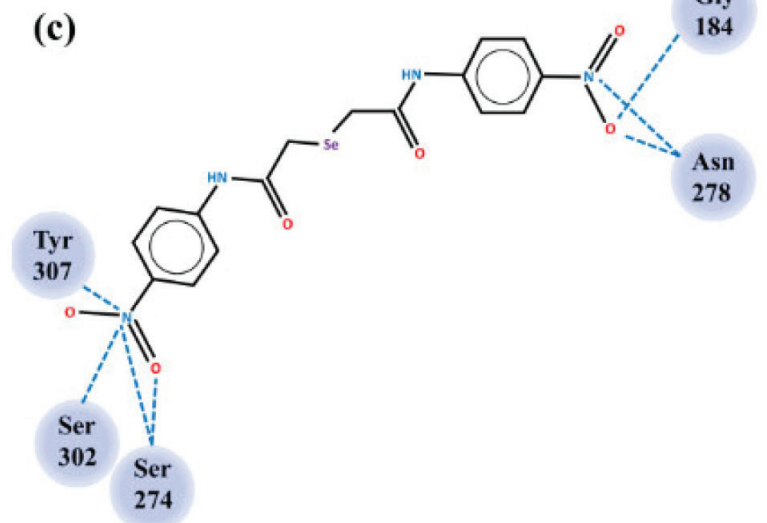

Prediction of absorption, distribution, metabolism, excretion, and toxicology (ADMET) properties

Pharmacokinetic parameters can be estimated to predict which substances are likely to present properties of pharmacological interest. The use of these parameters to predict biological properties that can interfere with absorption, distribution, metabolism, excretion and toxicology (ADMET) have been applied in recent years. ${ }^{18,19}$ Determining these properties can provide information regarding the permeability and the concentrations of certain compounds for therapeutic targets and the consequent elimination from the organism. ${ }^{18,19}$ ADMET parameters can be verified by in silico studies, based on the calculations of physicochemical properties, such as lipophilicity $(\operatorname{cog} \mathrm{P})$, solubility in water $(\log \mathrm{S})$, and molecular weight (MW).

In this study, an in silico analysis of the selenide derivatives was performed to verify the Lipinski's parameters, using the software OSIRIS Property Explorer ${ }^{20}$ and SwissADME. ${ }^{21}$ In addition, other parameters such as rotating bonds $(\mathrm{Rb})$, the topological polar surface area (TPSA), absorption percentage (ABS), and drug score, were also included in the study, as these
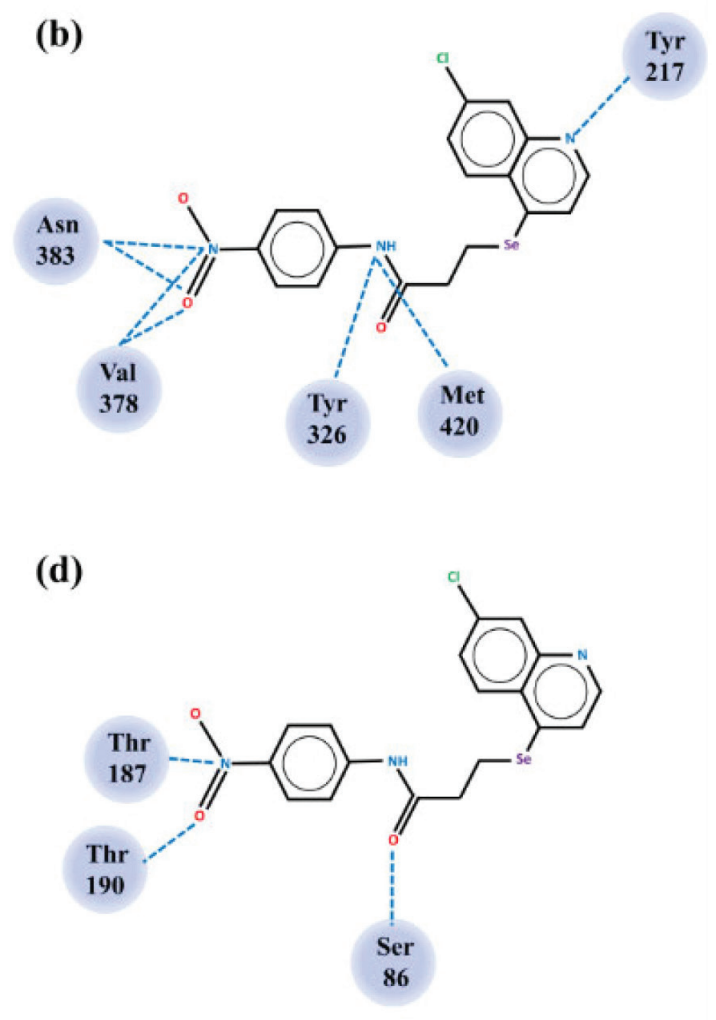

Figure 1. Lowest-energy dock positions and respective energies (kcal mol ${ }^{-1}$ ) of selenoderivatives with the tested enzymes. (a) 4g with NMT (-139.96); (b) 7n with NMT (-140.10); (c) 4g with OASS (-145.85); and (d) 7n with OASS (-154.27). Dashed lines represent hydrogen-bond interactions. 
Table 3. In silico studies evaluating Lipinski's rule of five, including topological surface area (TPSA), absorption percentage (ABS), rotatable bonds, drug-likeness, and the drug score, for the compounds $\mathbf{4 f}, \mathbf{4 g}, \mathbf{4 h}, \mathbf{4 l}, \mathbf{4 m}, \mathbf{7 j}$, and $\mathbf{7 n}$

\begin{tabular}{|c|c|c|c|c|c|c|c|c|c|}
\hline \multirow{2}{*}{ Compound } & \multicolumn{5}{|c|}{ Lipinski parameter } & \multirow{2}{*}{$\mathrm{Rb}$} & \multirow{2}{*}{ TPSA / $\AA^{2}$} & \multirow{2}{*}{$\mathrm{ABS} / \%$} & \multirow{2}{*}{ Drug score } \\
\hline & MW & HBD & HBA & $\operatorname{clog} \mathrm{P}$ & $\mathrm{nV}$ & & & & \\
\hline $4 f$ & 407.32 & 2 & 4 & 1.52 & 0 & 10 & 76.66 & 82.55 & 0.41 \\
\hline $4 g$ & 437.27 & 2 & 6 & 0.47 & 0 & 10 & 149.84 & 57.30 & 0.35 \\
\hline $4 h$ & 375.32 & 2 & 2 & 2.17 & 0 & 10 & 58.20 & 88.92 & 0.39 \\
\hline 41 & 533.12 & 2 & 2 & 3.27 & 1 & 10 & 58.20 & 88.92 & 0.12 \\
\hline $4 m$ & 435.38 & 2 & 4 & 2.07 & 0 & 12 & 76.66 & 82.55 & 0.36 \\
\hline $7 \mathbf{j}$ & 402.78 & 1 & 1 & 3.79 & 0 & 8 & 29.10 & 98.96 & 0.16 \\
\hline $7 n$ & 419.72 & 1 & 3 & 2.70 & 0 & 8 & 74.92 & 83.15 & 0.23 \\
\hline
\end{tabular}

MW: molecular weight, HBD: hydrogen bonding donor; HBA: hydrogen bonding acceptor; clog P: octanol/water partition coefficient based on Molinspiration milogP model; $\mathrm{nV}$ : number of violations; $\mathrm{Rb}$ : rotatable bonds; TPSA: total polar surface area; ABS: absorption percentage.

represent important parameters that are considered when designing and evaluating novel drug candidates. The absorption percentage was calculated using the equation $\operatorname{ABS}(\%)=109-(0.345 \times$ TPSA $)$, as described by Zhao et al. ${ }^{22}$ The values calculated in this study are shown in Table 3.

The in silico results, described in Table 3, showed that the selected compounds, which were identified as most likely to be active in the combined approach, followed Lipinski's rules which included: molar mass $\leq 500 \mathrm{~g} \mathrm{~mol}^{-1}$, $\log \mathrm{P} \leq 5$, number of hydrogen acceptors $\leq 10$ (determined as a function of the number of $\mathrm{N}$ or $\mathrm{O}$ atoms in the molecule), and number of hydrogen bonding donors $\leq 5$ (represented as a function of the number of $\mathrm{NH}$ or $\mathrm{OH}$ groups in the molecule). Only compound $\mathbf{4 l}$ registered a subtle violation, for the MW parameter, which is permitted by the rule. Predictions of oral absorption percentages were also calculated from the TPSAs, and the results ranged from $57.30 \%$ ( $\mathbf{4 g}$ ) to $98.96 \%$ (7j), indicating that the derivatives present good permeability across the plasma membrane of cells. When analyzing the values of the drug score (DS), which combines clogP, $\log \mathrm{S}, \mathrm{MW}$, and toxicity risks for a given species, variations from 0.12 (4I) to 0.41 (4f) were observed, indicating that these compounds have the potential for new drug development. The DS is calculated as a numerical value ranging from 0.0 to $1.0 .{ }^{18,19}$

\section{Chemistry}

The synthesis of the target molecules was performed according to a procedure adapted from Lira $e t a l .{ }^{23}$ and Souza et al. $;^{14}$ thus, seven unheard-of selenides $(\mathbf{4 f}, \mathbf{4 g}$, $\mathbf{4 h}, \mathbf{4 l}, \mathbf{4 m}, \mathbf{7} \mathbf{j}$, and $\mathbf{7 n}$ ) were obtained, with good yields, derived from 7-amino-quinoline and $N$-phenylacetamides chlorides, as described in Scheme 1.
The first stage was the preparation of nucleophilic selenium species (2). The synthesis process used elemental selenium, in its solid, amorphous form ( $\mathrm{Se}^{0}$, black powder), which is the most abundant form of selenium in nature. Selenium was reduced through a reaction with sodium boron hydride $\left(\mathrm{NaBH}_{4}\right)$, which produces an intense release of hydrogen gas and the reactive species of interest (NaHSe), in the presence of ethanol. ${ }^{24}$ The reaction was considered complete after the total consumption of selenium. The second stage was performed as a "one-pot" reaction. Dimethylformamide (DMF) was added to the reaction medium, followed by the respective phenylacetamides chlorides ( $\mathbf{3 f}, \mathbf{3 g}, \mathbf{3 h}, \mathbf{3 l}$, and $\mathbf{3 m}$ ), under stirring conditions and at room temperature, which resulted in the formation of the respective bis-selenides $(\mathbf{4 f}, \mathbf{4 g}, \mathbf{4 h}, \mathbf{4 l}$, and $\mathbf{4 m}$ ), with yields between $70-80 \%$.

The bis-selenide structures were confirmed using infrared (IR), ${ }^{1} \mathrm{H},{ }^{13} \mathrm{C}$ nuclear magnetic resonance (NMR) spectroscopic techniques and high resolution mass spectromety (HRMS). Analyzing the NMR spectra of the $\mathbf{4 f}$ compound, taking into account its $\mathbf{3 f}$ slapper, a signal shift was observed, referring to the H-6 hydrogens that were previously observed at $4.90 \mathrm{ppm}$ and later at $3.38 \mathrm{ppm}$, due to the replacement of the chlorine element by selenium. A similar trend was observed for the entire series of compounds. The other signals undergo small modifications due to the new interactions, including a singlet at $10.02 \mathrm{ppm}$, referring to hydrogen linked to nitrogen, a set of doublets at 6.88 and $7.49 \mathrm{ppm}$, referring to aromatic hydrogens. As the sub-substitution of this compound and the methoxy group, a singlet referring to $\mathrm{CH}_{3}$ hydrogens is presented at $3.71 \mathrm{ppm}$.

The same shielding effect of selenium was observed on the ${ }^{13} \mathrm{C}$ NMR spectra, where the C-6 carbon moves from $43.0 \mathrm{ppm}(\mathbf{3 f})$ to the most shielded region, at 
$26.88 \mathrm{ppm}$ (4f). Considering the electron donor and electron acceptor characteristics of the substituents, the following signals were observed: $\mathrm{C}-5(\mathrm{C}=\mathrm{O})$ at $168.20 \mathrm{ppm}$, the aromatic carbons $\mathrm{C}-1(\mathrm{C}-\mathrm{O})$ at $155.30 \mathrm{ppm}, \mathrm{C}-4(\mathrm{C}-\mathrm{N})$ at 113.90 ppm, C-3,3' at 120.66 ppm, C-2,2' at 113.90 ppm, the carbon of the methoxy group is present in $55.19 \mathrm{ppm}$.

To obtain the selenides (7j and $\mathbf{7 n}$ ), the same NaHSe production procedure was performed, followed by the addition of 3,7-dichloro-quinoline, which is a reaction that has not been described in the literature, giving rise to intermediate $\mathbf{6}$. The reaction proceeded with the addition of $N$-phenylacetamides chlorides, generating the compounds $\mathbf{7 j}$ and $\mathbf{7 n}$, with yields of 64.5 and $71.8 \%$, respectively.

The selenide structures were confirmed using ${ }^{1} \mathrm{H}$, ${ }^{13} \mathrm{C}$ NMR and HRMS spectroscopic techniques. When analyzing the ${ }^{1} \mathrm{H}$ NMR spectrum (200 MHz, using DMSO- $d_{6}$ ) of compound $\mathbf{7 n}$, seven signs were observed in the aromatic region: $\mathrm{H}-8$ at $8.73 \mathrm{ppm}(\mathrm{d}), \mathrm{H}-17,15$ at $8.12 \mathrm{ppm}$ (d), H-3 at $7.96 \mathrm{ppm}$ (s), H-18,14 at $7.77 \mathrm{ppm}$ (d), H-6 at 7.69 ppm (d), H-1 at 7.61 ppm (d) and H-9 at $7.51 \mathrm{ppm}(\mathrm{d})$. In the high-field region, signs referring to H-11 hydrogens were noted, at 3.90 ppm. Lastly, in the lower field, amidic hydrogen was identified, in the region of $10.21 \mathrm{ppm}(\mathrm{s})$.

In the ${ }^{13} \mathrm{C}$ NMR spectrum (50 MHz, DMSO- $d_{6}$ ), signals corresponding to the carbon atoms of this compound were observed. Seventeen total carbons were identified in the molecule. The molecule contains four carbons with overlapping signals, carbons C-14,18 and C-15,17. Their intensity makes it easy to separate them from the other aromatic signals located in the region of 130.0 (C-15,17) and $119.0 \mathrm{ppm}(\mathrm{C}-14,18)$, still in the region aromatic and it is possible to distinguish the signals taking into account the percussive compounds discriminating the carbons as 149.8 (C-8), 145.3 (C-2), 144.1 (C-13), 136.0 (C-3), 134.9 (C-4), 129.7 (C-10), 128.9 (C-16), 127.6 (C-6), 126.5 (C-1), 126.5 (C-16), 125.3 (C-5), 123.6 (C-9). In the high field region, we have the signal referring to carbonyl carbon that is present in the lower field region at $169.3 \mathrm{ppm}(\mathrm{C}-12)$, the other signals in the low field region are identified as $\mathrm{C}-11$ at $39.0 \mathrm{ppm}$ and $\mathrm{C}-7$ at $37.6 \mathrm{ppm}$. These measurements were taken relative to the percussion of the final molecule, and these molecules have already been elucidated in the literature. The molecular mass of the compounds, $\mathbf{4 f}, \mathbf{4 g}$, $\mathbf{4 h}, \mathbf{4 l}, \mathbf{4 m}, \mathbf{7} \mathbf{j}$ and $\mathbf{7 n}$, were confirmed by spectra copying masses of high resolution.

\section{Biological study}

After using the selenide screening model, the compounds that were identified as likely to be active, with a probability above $50 \%$ for at least one of the species, were selected for in vitro tests against the promastigote forms of L. amazonensis (IFLA/BR/1967/PH8), which are species available in our laboratory. Compounds $\mathbf{4 f}, \mathbf{4 g}$, $\mathbf{4 h}, \mathbf{4 l}, \mathbf{4 m}, \mathbf{7 j}$, and $\mathbf{7 n}$ were selected, and all were found to be effectively active against $L$. amazonensis cells, with $\mathrm{IC}_{50}$ values ranging from 5.67-221.6 $\mu \mathrm{g} \mathrm{mL} \mathrm{m}^{-1}$ (Table 1). In particular, compounds $\mathbf{7 n}$ and $\mathbf{4 g}$ demonstrated $\mathrm{IC}_{50}$ values of 5.67 and $10.81 \mu \mathrm{g} \mathrm{mL}^{-1}$, respectively. After the good results against $L$. amazonensis, cytotoxicity tests were also performed against peripheral blood mononuclear cells (PBMCs), to determine whether the compounds were selective for parasitic cells. All compounds were found to be selective, with selectivity index (SI) values ranging from 70.5-1.8. Again, compounds $\mathbf{7 n}$ and $\mathbf{4 g}$ were also the most selective, in addition to being the most active, showing very promising potential as new drugs.

\section{Conclusions}

Our in silico study used a combined approach, based on the structures of both the ligand and the receptor, which identified the molecules $\mathbf{4 f}, \mathbf{4 g}, \mathbf{4 h}, \mathbf{4 l}, \mathbf{4 m}, \mathbf{7 j}$, and $\mathbf{7 n}$ as being potentially active against at least one of the species L. donovani and L. amazonensis. These molecules were also examined using Lipinski's filters and did not violate any of the rules, suggesting that they have potential as new drugs. These seven compounds, which are new molecules, were synthesized, and their structures were confirmed by IR, ${ }^{1} \mathrm{H}$, and ${ }^{13} \mathrm{C}$ NMR. Subsequently, they were subjected to cytotoxicity tests against L. amazonensis cells and PBMCs, to calculate SI values. All compounds were shown to be active and selective, especially $\mathbf{7 n}$ and $\mathbf{4 g}$, which presented $\mathrm{IC}_{50}$ values of 5.67 and $10.81 \mu \mathrm{g} \mathrm{mL}^{-1}$, respectively, against L. amazonensis and SI values of 70.5 and 37.0, when cytotoxicity against L. amazonensis was compared with toxicity against PBMCs. For the two most active molecules, their interaction energies were analyzed in detail, through molecular docking studies, with four Leishmania enzymes. The studied molecules showed better anchorage profiles with NMT and OASS, suggesting that these molecules may exert their leishmanicidal effects by inhibiting these enzymes; however, further studies are necessary to unequivocally elucidate the mechanisms of action for these molecules.

\section{Experimental}

In silico study

The VS methodology (LB and SB approaches) used the same databases for $L$. donovani and L. amazonensis, 
in addition to the same target enzymes, that were used in previous studies performed by our group, to screen selenides with active potential. ${ }^{7,8}$

\section{Chemistry}

All reagents and solvents were purchased from commercial sources (Sigma-Aldrich, São Paulo, Brazil) and used without further purification. The progress of the reactions was monitored by thin-layer chromatography (TLC) on silica gel plates. The purification of the compounds was performed by recrystallization in ethanol and confirmed by determining the melting ranges of each compound on an MQAPF-3 brand hotplate. The IR spectra were obtained on a Shimadzu model IR Prestige-21 FTIR spectrometer, using attenuated total reflection. ${ }^{1} \mathrm{H}$ and ${ }^{13} \mathrm{C}$ NMR spectra were obtained with a Bruker Avance Ultrashield ${ }^{\mathrm{TM}}\left(200 \mathrm{MHz}\right.$ for ${ }^{1} \mathrm{H}$ and $50 \mathrm{MHz}$ for $\left.{ }^{13} \mathrm{C}\right)$. Deuterated chloroform $\left(\mathrm{CDCl}_{3}\right)$ and deuterated dimethyl sulfoxide (DMSO) were used as solvents, and tetramethylsilane (TMS) was used as the internal standard. Chemical shifts $(\delta)$ were measured in parts per million (ppm), and the coupling constants $(J)$ were measured in hertz $(\mathrm{Hz})$. High resolution mass (HRMS) analysis was obtained with time-of-flight (TOF) mass spectrometer (microTOFII-Bruker) instrument using electron impact ionization (EI) and reported as $\mathrm{m} / \mathrm{z}$ (relative intensity) for the molecular ion [M] and reporting the molecular ion $[\mathrm{M}+\mathrm{H}]^{+}$.

General procedure for the preparation of $N$-phenylacetamide chlorides

In a $50 \mathrm{~mL}$ flask, $20 \mathrm{mmol}$ of $p$-substituted arylamine and $24 \mathrm{mmol}$ of triethylamine $\left(\mathrm{Et}_{3} \mathrm{~N}\right)$ were added to $20 \mathrm{~mL}$ dichloromethane, under constant stirring, at a temperature of $0{ }^{\circ} \mathrm{C}$, which was controlled by a crushed ice bath. After a brief period, $24 \mathrm{mmol}$ of 2-chloro-acetyl/3-chloropropyl chloride was added slowly. Then, the ice bath was removed, and the reaction remained under constant stirring and at room temperature for $24 \mathrm{~h}$. At the end of the reaction, the solvent was removed, under reduced pressure. The resulting precipitate was washed with distilled water, vacuum filtered, and recrystallized in a suitable ethanol/water solution. This procedure yielded a crystalline form.

\section{2-Chloro- $N$-(4-methoxyphenyl) propanamide (3f)}

Yellow solid; yield 84\%; mp 184-186 ${ }^{\circ} \mathrm{C}$; IR (ATR) $\mathrm{v} / \mathrm{cm}^{-1}$ 3263, $3194(\mathrm{NH}), 3124,3076\left(\mathrm{CH}_{\mathrm{Ar}}\right), 2999,2953$ $\left(\mathrm{CH}_{\text {Alip }}\right), 1670(\mathrm{C}=\mathrm{O}), 1610,1550\left(\mathrm{C}=\mathrm{C}_{\mathrm{Ar}}\right), 1281,1246$
$(\mathrm{C}-\mathrm{Cl}), 1188(\mathrm{C}-\mathrm{Br}), 1072,860\left(\mathrm{CH}_{\mathrm{Ar}}\right), 736(\mathrm{NH}), 497$ $\left(\mathrm{C}-\mathrm{C}_{\mathrm{Ar}}\right) ;{ }^{1} \mathrm{H}$ NMR $\left(200 \mathrm{MHz}, \mathrm{DMSO}-d_{6}\right) \delta 4.53(\mathrm{~s}, 3 \mathrm{H}$, $\left.\mathrm{CH}_{3}\right), 4.90\left(\mathrm{~s}, 2 \mathrm{H}, \mathrm{CH}_{2}\right), 7.62\left(\mathrm{~d}, 2 \mathrm{H}, \mathrm{CH}_{\mathrm{Ar}}\right), 8.17$ (d, 2H, $\left.\mathrm{CH}_{\mathrm{Ar}}\right), 10.87$ (s, $\left.1 \mathrm{H}, \mathrm{NH}\right) ;{ }^{13} \mathrm{C} \mathrm{NMR}\left(50 \mathrm{MHz}, \mathrm{DMSO}-d_{6}\right)$ $\delta 163.9,157.2,129.8,122.2,114.3,77.8,77.2,76.5,55.6$, $55.6,42.9$.

\section{2-Chloro- $\mathrm{N}$-(4-nitrophenyl)acetamide (3g)}

Yellow solid; yield $80 \%$; mp $189{ }^{\circ} \mathrm{C}$; IR (ATR) $\mathrm{v} / \mathrm{cm}^{-1}$ $3227(\mathrm{NH}), 3109,3070\left(\mathrm{CH}_{\mathrm{Ar}}\right), 2939,2825\left(\mathrm{CH}_{\text {Alip }}\right), 1688$ $(\mathrm{C}=\mathrm{O}), 1624,1506\left(\mathrm{C}=\mathrm{C}_{\mathrm{Ar}}\right), 1597,1338\left(\mathrm{NO}_{2}\right), 1294,1255$ $(\mathrm{C}-\mathrm{Cl}), 1172,869,850\left(\mathrm{C}-\mathrm{N}\right.$ of $\left.\mathrm{ArNO}_{2}\right), 1111,829\left(\mathrm{CH}_{\mathrm{Ar}}\right)$, $748(\mathrm{NH}), 526\left(\mathrm{C}-\mathrm{C}_{\mathrm{Ar}}\right) ;{ }^{1} \mathrm{H}$ NMR $\left(200 \mathrm{MHz}, \mathrm{DMSO}-d_{6}\right)$ $\delta 4.36$ (d, 2H, J $2.3 \mathrm{~Hz}, \mathrm{CH}_{2}$ ), 7.85 (dt, 2H, J 10.2, $2.7 \mathrm{~Hz}$, $\left.\mathrm{CH}_{\mathrm{Ar}}\right), 8.26\left(\mathrm{dt}, 2 \mathrm{H}, \mathrm{CH}_{\mathrm{Ar}}\right), 10.93(\mathrm{~s}, 1 \mathrm{H}, \mathrm{NH}) ;{ }^{13} \mathrm{C} \mathrm{NMR}$ $\left(50 \mathrm{MHz}, \mathrm{DMSO}-d_{6}\right) \delta 165.6,144.6,142.6,125.1,119.1$, $43.62,40.8,40.4,39.9,39.5,39.1,38.7,38.3$.

\section{3-Chloro- $N$-phenylpropanamide (3h)}

White solid; yield 87\%; mp $121{ }^{\circ} \mathrm{C}$; ${ }^{1} \mathrm{H} \mathrm{NMR}(200 \mathrm{MHz}$, DMSO- $\left.d_{6}\right) \delta 8.18(\mathrm{~s}, 1 \mathrm{H}), 7.56(\mathrm{~d}, J 15.0 \mathrm{~Hz}, 2 \mathrm{H}), 7.30(\mathrm{t}$, $J 14.9 \mathrm{~Hz}, 2 \mathrm{H}), 7.07$ (t, J 13.4 Hz, 1H), 3.89 (t, J $15.9 \mathrm{~Hz}$, $2 \mathrm{H}), 2.83(\mathrm{t}, J 16.0 \mathrm{~Hz}, 2 \mathrm{H}) ;{ }^{13} \mathrm{C} \mathrm{NMR}\left(50 \mathrm{MHz}, \mathrm{DMSO}-d_{6}\right)$ $\delta 168.3,137.9,128.9,123.7,120.9,39.4,36.6$.

\section{3-Chloro-N-(4-bromophenyl)propanamide (3I)}

Yellow solid; yield 69\%; mp 125-127 ${ }^{\circ} \mathrm{C}$; IR (ATR) $\mathrm{v} / \mathrm{cm}^{-1} 3290(\mathrm{~N}-\mathrm{H}), 3138,3070\left(\mathrm{C}-\mathrm{H}_{\mathrm{Ar}}\right), 2964\left(\mathrm{C}-\mathrm{H}_{\text {Alip }}\right)$, $1656(-\mathrm{N}-\mathrm{CO}), 1604$ and $1487\left(\mathrm{C}=\mathrm{C}_{\mathrm{Ar}}\right)$; ${ }^{1} \mathrm{H}$ NMR $\left(400 \mathrm{MHz} \mathrm{CDCl}_{3}\right) \delta 8.59(\mathrm{~s}, 1 \mathrm{H}), 7.94(\mathrm{~s}, 4 \mathrm{H}), 4.31(\mathrm{t}$, $J 15.9 \mathrm{~Hz}, 2 \mathrm{H}), 3.25(\mathrm{t}, J 15.9 \mathrm{~Hz}, 2 \mathrm{H}) ;{ }^{13} \mathrm{C} \mathrm{NMR}(101 \mathrm{MHz}$, $\left.\mathrm{CDCl}_{3}\right) \delta 165.3,143.7,138.9,127.8,123.5,46.4,43.6$.

3-Cloro- $\mathrm{N}$-(4-methoxyphenyl)propanamide (3m)

Yellow solid; yield 72\%; mp 125-127 ${ }^{\circ} \mathrm{C}$; IR (ATR) v / cm $3278(\mathrm{~N}-\mathrm{H}), 3138,3005\left(\mathrm{C}-\mathrm{H}_{\mathrm{Ar}}\right), 2953,2904$ $\left(\mathrm{C}-\mathrm{H}_{\mathrm{Alip}}\right), 1651(-\mathrm{N}-\mathrm{CO}), 1602$ and $1508\left(\mathrm{C}=\mathrm{C}_{\mathrm{AR}}\right), 1240$ and $1029(\mathrm{C}-\mathrm{O}) ;{ }^{1} \mathrm{H}$ NMR $\left(400 \mathrm{MHz}, \mathrm{CDCl}_{3}\right) \delta 7.61(\mathrm{~s}$, $1 \mathrm{H}, \mathrm{N}-\mathrm{H}), 7.39\left(\mathrm{~d}, 2 \mathrm{H}, \mathrm{CH}_{\mathrm{Ar}}\right), 6.83\left(\mathrm{~d}, 2 \mathrm{H}, \mathrm{CH}_{\mathrm{Ar}}\right), 3.85$ (t, $\left.2 \mathrm{H}, \mathrm{CH}_{2}\right), 3.77\left(\mathrm{~s}, 3 \mathrm{H}, \mathrm{OCH}_{3}\right), 2.77\left(\mathrm{t}, 2 \mathrm{H}, \mathrm{CH}_{2}\right) ;{ }^{13} \mathrm{C} \mathrm{NMR}$ $\left(101 \mathrm{MHz} \mathrm{CDCl}_{3}\right) \delta 167.9,156.8,130.7,122.3,114.3$, $55.6,40.4,40.2$.

\section{Preparation of 2,2'-selene-bis ( $N$-phenylacetamides)}

An amount equal to $20 \mathrm{~mL}$ of the solid mixture, consisting of $2.5 \mathrm{mmol}$ elemental selenium and $5.0 \mathrm{mmol} \mathrm{NaBH}_{4}$, was placed in a flask. The mixture was stirred continuously until the mixture became homogeneous at room temperature. Next, $5.0 \mathrm{mmol}$ ethanol was added, dropwise, followed by the dropwise addition of $5 \mathrm{~mL}$ DMF. During the course of 
this reaction, the color of the mixture abruptly changed to a dark color, and the reaction was left to stand for $5 \mathrm{~min}$. Then, $5.0 \mathrm{mmol}$ 2-chloro- $N$-phenylacetamide was dissolved in $5 \mathrm{~mL}$ DMF and added to the reaction mixture, which remained at room temperature under constant stirring. For the purification process, $20 \mathrm{~mL}$ distilled water was added, which promoted the formation of a precipitate, which was filtered and recrystallized with an appropriate solvent. This procedure yielded a crystalline form (white crystals with a fibrous appearance).

2,2'-Selene-bis( $\mathrm{N}$-(4-metoxyphenyl)acetamide) (4f)

White solid; yield 79\%; mp $204{ }^{\circ} \mathrm{C}$; IR (ATR) $\mathrm{v} / \mathrm{cm}^{-1}$ $1608(\mathrm{C}=\mathrm{O}), 1506(\mathrm{C}=\mathrm{C}), 1246(\mathrm{C}-\mathrm{O}), 823(\mathrm{~N}-\mathrm{H}), 742$ $(\mathrm{C}-\mathrm{Se}) ;{ }^{1} \mathrm{H}$ NMR $\left(200 \mathrm{MHz}, \mathrm{DMSO}-d_{6}\right) \delta 10.02$ (s, 2H, $\mathrm{N}-\mathrm{H}), 7.49$ (d, J 9.0 Hz, 4H, H-3,3'), 6.88 (d, J 9.0 Hz, 4H, H-2,2'), 3.71 (s, 6H, $\mathrm{CH}_{3}$ ), 3.38 (s, 4H, H-6); ${ }^{13} \mathrm{C} \mathrm{NMR}$ $\left(101 \mathrm{MHz}, \mathrm{DMSO}-d_{6}\right) \delta 168.2(\mathrm{C}=\mathrm{O}), 155.3(\mathrm{C}-1), 132.2$ (C-4), 120.7 (C-3,3'), 113.9 (C-2,2'), $55.2\left(\mathrm{CH}_{3}\right), 26.9$ (C-6); HRMS (FTMS + pESI) $m / z$, calcd. for $\mathrm{C}_{18} \mathrm{H}_{20} \mathrm{~N}_{2} \mathrm{O}_{4} \mathrm{Se}$ $[\mathrm{M}]^{+}:$409.0667, found: 409.0682.

\section{2,2'-Selene-bis( $N$-(4-nitrophenyl)acetamide) (4g)}

Yellow solid; yield $72.3 \%$; mp $232-234{ }^{\circ} \mathrm{C}$; IR (ATR) $\mathrm{v} / \mathrm{cm}^{-1} 1662(\mathrm{C}=\mathrm{O}), 1550(\mathrm{C}=\mathrm{C}), 850\left(\mathrm{NO}_{2}\right), 748(\mathrm{~N}-\mathrm{H})$, 686 (Se-C); ${ }^{1} \mathrm{H}$ NMR (200 MHz, DMSO- $\left.d_{6}\right) \delta 10.71(\mathrm{~s}, 2 \mathrm{H}$, $\mathrm{N}-\mathrm{H}), 8.19$ (d, J9.2 Hz, 4H, H-2,2'), 7.79 (d, J9.3 Hz, 4H, $\mathrm{H}-3,3$ ') 3.33 (s, 4H, H-6); ${ }^{13} \mathrm{C}$ NMR (50 MHz, DMSO- $d_{6}$ )

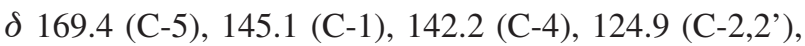
118.7 (C-3,3'), 27.0 (C-6); HRMS (FTMS + pESI) $\mathrm{m} / \mathrm{z}$, calcd. for $\mathrm{C}_{18} \mathrm{H}_{20} \mathrm{~N}_{2} \mathrm{O}_{4} \mathrm{Se}[\mathrm{M}]^{+}$: 439.0157, found: 439.0164 .

\section{3,3'-Selene-bis( $N$-phenylpropanamide) (4h)}

White solid; yield $72.3 \%$; $\mathrm{mp} 165^{\circ} \mathrm{C}$; IR (ATR) $\mathrm{V} / \mathrm{cm}^{-1}$ $3305(\mathrm{C}-\mathrm{H}), 1651(\mathrm{C}=\mathrm{O}), 1529(\mathrm{C}=\mathrm{C}), 742(\mathrm{~N}-\mathrm{H}), 690$ $(\mathrm{C}-\mathrm{Se}) ;{ }^{1} \mathrm{H} \mathrm{NMR}\left(200 \mathrm{MHz}, \mathrm{DMSO}-d_{6}\right) \delta 9.83(\mathrm{~s}, 1 \mathrm{H}$, $\mathrm{N}-\mathrm{H}), 7.53$ (d, J $\left.8.2 \mathrm{~Hz}, 2 \mathrm{H}, \mathrm{H}-3,3^{\prime}\right), 7.18$ (t, J $7.8 \mathrm{~Hz}$, 2H, H-2,2'), 6.95 (t, J 7.3 Hz, 1H, H-1), 3.16 (t, J 7.0 Hz, 1H, H-6), 2.80 (t, J $5.5 \mathrm{~Hz}, 2 \mathrm{H}, \mathrm{H}-7) ;{ }^{13} \mathrm{C}$ NMR (50 MHz, DMSO- $\left.d_{6}\right) \delta 169.6$ (C-5), 138.7 (C-4), 128.3 (C-3,3'), 123.0 (C-1), 119.2 (C-2,2'), 37.8 (C-6), 24.5 (C-7); HRMS (FTMS + pESI) $m / z$, calcd. for $\mathrm{C}_{18} \mathrm{H}_{20} \mathrm{~N}_{2} \mathrm{O}_{4} \mathrm{Se}[\mathrm{M}]^{+}$: 377.0768, found: 377.0769 .

\section{3,3'-Selene-bis( $N$-(4-bromophenyl)propanamide) (4I)}

Purple solid; yield 83.4\%; mp $203{ }^{\circ} \mathrm{C}$; IR (ATR) $\mathrm{V} / \mathrm{cm}^{-1}$ $1655(\mathrm{C}=\mathrm{O}), 1526(\mathrm{C}=\mathrm{C}), 1226(\mathrm{C}-\mathrm{Cl}), 820(\mathrm{~N}-\mathrm{H})$, $681(\mathrm{C}-\mathrm{Se}) ;{ }^{1} \mathrm{H}$ NMR $\left(200 \mathrm{MHz}, \mathrm{DMSO}-d_{6}\right) \delta 7.70(\mathrm{~s}$, 2H, N-H), 7.41 (m, J $\left.8.8 \mathrm{~Hz}, 8 \mathrm{H}, \mathrm{H}-2,2^{\prime}, 3,3^{\prime}\right), 3.85$ (t, $J 7.2 \mathrm{~Hz}, 4 \mathrm{H}, \mathrm{H}-6), 2.80$ (t, $J 5.5 \mathrm{~Hz}, 4 \mathrm{H}, \mathrm{H}-7) ;{ }^{13} \mathrm{C}$ NMR $\left(50 \mathrm{MHz}, \mathrm{DMSO}-d_{6}\right) \delta 168.1$ (C-5), 136.6 (C-4), 132.1
(C-3,3'), 121.9 (C-2,2'), 117.5 (C-1), 40.5 (C-6), 39.9 (C-7); HRMS (FTMS + pESI) $m / z$, calcd. for $\mathrm{C}_{18} \mathrm{H}_{20} \mathrm{~N}_{2} \mathrm{O}_{4} \mathrm{Se}$ $[\mathrm{M}]^{+}:$534.8958, found: 534.8938 .

\section{3,3'-Selene-bis( $N$-( $p$-methoxy)propanamide) (4m)}

White solid; yield $84.5 \%$; $\mathrm{mp} 160{ }^{\circ} \mathrm{C}$; IR (ATR) $\mathrm{v} / \mathrm{cm}^{-1}$ $2914\left(\mathrm{CH}_{3}\right), 1649(\mathrm{C}=\mathrm{O}), 1521(\mathrm{C}=\mathrm{C}), 814(\mathrm{~N}-\mathrm{H}), 665$ $(\mathrm{C}-\mathrm{Se}) ;{ }^{1} \mathrm{H}$ NMR $\left(200 \mathrm{MHz}, \mathrm{DMSO}-d_{6}\right) \delta 7.61(\mathrm{~s}, 1 \mathrm{H}$, $\mathrm{N}-\mathrm{H}), 7.39$ (d, J $8.4 \mathrm{~Hz}, 4 \mathrm{H}, \mathrm{H}-3,3$ '), 6.83 (d, J $8.1 \mathrm{~Hz}$, 4H, H-2,2'), 3.85 (t, J $7.2 \mathrm{~Hz}, 4 \mathrm{H}, \mathrm{H}-6), 3.77$ (s, 6H, $\mathrm{CH}_{3}$ ), 2.77 (t, J $\left.7.3 \mathrm{~Hz}, 4 \mathrm{H}, \mathrm{H}-7\right)$; ${ }^{13} \mathrm{C} \mathrm{NMR} \mathrm{(50} \mathrm{MHz,}$ DMSO- $\left.d_{6}\right) \delta 167.9(\mathrm{C}-5), 130.7$ (C-1), 122.3 (C-4), 114.3 (C-3,3'), 119.1 (C-2,2'), 37.5 (C-6), $20.3\left(\mathrm{CH}_{3}\right), 18.2$ (C-7); HRMS (FTMS + pESI) $m / z$, calcd. for $\mathrm{C}_{18} \mathrm{H}_{20} \mathrm{~N}_{2} \mathrm{O}_{4} \mathrm{Se}[\mathrm{M}]^{+}$: 437.0901, found: 437.0906 .

\section{Preparation of quinoline-derived selenides}

In a $50 \mathrm{~mL}$ flask, $0.1 \mathrm{~g}(1.6 \mathrm{mmol})$ elemental selenium and $0.1 \mathrm{~g}(3.2 \mathrm{mmol}) \mathrm{NaBH}_{4}$ were combined. The mixture was stirred continuously until it became homogeneous. Next, $2 \mathrm{~mL}$ of ethanol were added, dropwise, resulting in the release of gas and heat. After the total release of hydrogen gas, $5 \mathrm{~mL}$ DMF were added. During the course of this reaction, the color of the mixture abruptly changed to a dark color, and the reaction was left to stand for $5 \mathrm{~min}$. Then, $0.25 \mathrm{~g}$ (1.6 mmol) 4,7-dichloroquinoline, in $5 \mathrm{~mL}$ DMF, was added to the flask, and the reaction was allowed to proceed for $30 \mathrm{~min}$. Then, the chlorides (3) are added, and this step continued for $4 \mathrm{~h}$. For the purification process, $20 \mathrm{~mL}$ distilled water was added, which promoted the formation of a precipitate, which was filtered and recrystallized with an appropriate solvent. This procedure yielded the crystalline form of the compound.

3-((7-Chloroquinoline-4-yl)selene)- $N$-(4-ethylphenyl) propanamide (7j)

White solid; yield 64.5\%; mp $119.5{ }^{\circ} \mathrm{C} ;{ }^{1} \mathrm{H}$ NMR (200 MHz, DMSO- $\left.d_{6}\right) \delta 10.49(\mathrm{~s}, 1 \mathrm{H}), 8.75$ (d, J 4.8 Hz, 1H, H-8), 7.98 (dd, J 12.4, 5.6 Hz, 2H, H-6,3), 7.80 (d, $J 4.8$ Hz, 1H, H-9), 7.54 (dd, J 14.3, 5.5 Hz, 3H, H-1,14,18), 7.21 (d, J 8.9 Hz, 2H, H-15,17), 3.21 (t, J8.3 Hz, 2H, H-11), $2.80(\mathrm{t}, J 8.3 \mathrm{~Hz}, 2 \mathrm{H}, \mathrm{H}-7), 2.60$ (q, J $6.6 \mathrm{~Hz}, 2 \mathrm{H}, \mathrm{CH}_{2}$ ), $1.18\left(\mathrm{t}, J 6.6 \mathrm{~Hz}, 3 \mathrm{H}, \mathrm{CH}_{3}\right) ;{ }^{13} \mathrm{C}$ NMR $\left(50 \mathrm{MHz}, \mathrm{DMSO}-d_{6}\right)$ $\delta 171.4$ (C-12), 152.4 (C-8), 148.2 (C-4), 145.1 (C-16), 142.3 (C-13), 140.3 (C-10), 138.5 (C-2), 134.8 (C-5), 131.3 (C-15,17), 129.6 (C-6), 128.6 (C-1), 127.5 (C-3), 123.3 (C-9), 121.1 (C-14,18), 39.4 (C-11), 31.9 (C-7), 21.6 $\left(\mathrm{CH}_{2}\right), 17.4\left(\mathrm{CH}_{3}\right)$; HRMS (FTMS + pESI) $\mathrm{m} / \mathrm{z}$, calcd. for $\mathrm{C}_{18} \mathrm{H}_{20} \mathrm{~N}_{2} \mathrm{O}_{4} \mathrm{Se}[\mathrm{M}]^{+}:$419.0351, found: 419.0368 . 
3-((7-Chloroquinoline-4-yl)selene)- $N$-(4-nitrophenyl) propanamide $\mathbf{( 7 n )}$

White solid; yield 71.8\%; mp $210{ }^{\circ} \mathrm{C} ;{ }^{1} \mathrm{H}$ NMR (200 MHz, DMSO- $d_{6}$ ) $\delta 10.64(\mathrm{~s}, 1 \mathrm{H}, \mathrm{N}-\mathrm{H}), 8.73$ (d, $J 4.8 \mathrm{~Hz}, 1 \mathrm{H}, \mathrm{H}-8), 8.12$ (d, J 12.4 Hz, 2H, H-17,15), 7.96 (s, 1H, H-3), 7.77 (d, J 14.3, 5.5 Hz, 2H, H-18,14), 7.69 (d, J $8.9 \mathrm{~Hz}, 1 \mathrm{H}, \mathrm{H}-6), 7.61$ (d, J 15.0 Hz, 1H, H-1), 7.51 (d, J 15.0 Hz, 1H, H-9), 3.90 (t, 2H, J 11.3 Hz, H-11), 2.92 (t, $J 11.3 \mathrm{~Hz}, 2 \mathrm{H}, \mathrm{H}-7) ;{ }^{13} \mathrm{C}$ NMR (50 MHz, DMSO- $d_{6}$ ) $\delta 169.3$ (C-12), 149.8 (C-8), 145.3 (C-4), 144.1 (C-13), 136.0 (C-16), 134.9 (C-2), 130.0 (C-15,17), 129.7 (C-10), 128.9 (C-3), 127.6 (C-6), 126.5 (C-1), 125.3 (C-5), 123.6 (C-9), 119.0 (C-14,18), 39.0 (C-11), 37.6 (C-7); HRMS (FTMS + pESI) $m / z$, calcd. for $\mathrm{C}_{18} \mathrm{H}_{20} \mathrm{~N}_{2} \mathrm{O}_{4} \mathrm{Se}[\mathrm{M}]^{+}$: 435.9889, found: 435.9897.

\section{Biological activity}

\section{Obtaining PBMC cells}

For cell isolation, a discontinuous Percoll gradient technique was employed. ${ }^{7,25,26}$ Peripheral blood mononuclear cells (PBMCs) were obtained from human peripheral blood and stored in vacuum tubes containing an anticoagulant (ethylenediaminetetraacetic acid (EDTA)). Whole-blood samples were first diluted in phosphate-buffered saline (PBS), at a ratio of $3 \mathrm{~mL}$ blood in $5 \mathrm{~mL}$ PBS (3:5). Commercial Percoll was diluted in PBS to obtain 40, 50 , and $70 \%$ solutions, and the $\mathrm{pH}$ was adjusted to 7.4. Subsequently, $3 \mathrm{~mL}$ of each concentration of Percoll (from the highest to the lowest density) was deposited in $15 \mathrm{~mL}$ polypropylene plastic tubes, resulting in a $9 \mathrm{~mL}$ total gradient. Aliquots containing $2 \mathrm{~mL}$ blood were deposited on top of the discontinuous gradient and centrifuged for $30 \mathrm{~min}$, at 2,000 rpm at room temperature. After centrifugation, the PBMC cloud was recovered and transferred to a new tube containing $11 \mathrm{~mL}$ PBS and centrifuged again, for $20 \mathrm{~min}$ at $1000 \mathrm{rpm}$. The pellet was resuspended in Roswell Park Memorial Institute (RPMI) 1640 medium, containing 20\% fetal bovine serum and $1 \%$ penicillin/streptomycin and amphotericin. Then, cell counting and viability determination were performed.

\section{Activity tests against $L$. amazonensis promastigotes}

The parasite Leishmania (Leishmania) amazonensis (IFLA/BR/1967/PH8), in promastigote form, was cultivated in Schneider's medium (Sigma-Aldrich, St. Louis, MO, USA), supplemented with $20 \%$ bovine fetal serum, $1 \%$ male human urine and antibiotics (penicillin $200 \mathrm{U} \mathrm{mL}^{-1}$ and streptomycin $0.1 \mathrm{mg} \mathrm{mL}^{-1}$ ) (Gibco, CA, USA). Cells were incubated in a biological oxygen demand (BOD) incubator, at $26{ }^{\circ} \mathrm{C}$. The colorimetric 3-(4,5-dimethylthiazol-2-yl)- 2,5-diphenyltetrazolium bromide (MTT) assay is based on the dehydrogenase activity of cytosolic and mitochondrial enzymes, which reduce MTT (yellow coloration) and form a blue formazan salt that is insoluble in water. The MTT assay was used to evaluate the anti-Leishmania activity of compounds $4 \mathbf{f}, \mathbf{4 g}, \mathbf{4 h}, \mathbf{4 l}, \mathbf{4 m}, \mathbf{7 j}$, and $\mathbf{7 n}$ and the cytotoxicity against PBMCs. Cell viability was used to calculate $\mathrm{IC}_{50}$ values. In a 96-well plate, $100 \mu \mathrm{L}$ supplemented Schneider medium and approximately $1 \times 10^{6} \mathrm{~L}$. amazonensis promastigotes or PBMCs were added to each well. Each compound was tested in triplicate. Compounds were diluted in supplemented Schneider medium, to a final volume of $100 \mu \mathrm{L}$ and concentrations of $100,50,25,12.5,6.25$, and $3.125 \mu \mathrm{g} \mathrm{mL}^{-1}$, of each compound previously diluted in half with Schneider DMSO. Then, the plate was incubated for $72 \mathrm{~h}$, in a BOD oven at $26^{\circ} \mathrm{C}$. At the end of incubation, $10 \mu \mathrm{L}$ of MTT, diluted in PBS, was added to each well at a final concentration of $5 \mu \mathrm{g} \mathrm{mL} \mathrm{m}^{-1}$. The plates were incubated for another $4 \mathrm{~h}$ in a BOD greenhouse, at $26^{\circ} \mathrm{C}$, and then $50 \mu \mathrm{L}$ $10 \%$ sodium dodecyl sulfate (Vetec ${ }^{\circledR}$, São Paulo, Brazil) was added. The plate was left overnight to allow the dissolution of formazan. Then, the absorbance of each well was read using a spectrophotometer (Spectramax Plus, Molecular Devices, Sunnyvale, CA, USA), at $570 \mathrm{~nm}$. The negative control was Schneider medium, supplemented with $0.2 \%$ DMSO. The positive control utilized amphotericin B as the reference drug. Assays were performed in triplicate and were repeated three times, on different days. GraphPad Prism software, version 5.0, ${ }^{27}$ was used to calculate the $\mathrm{IC}_{50} \cdot{ }^{26}$

\section{Supplementary Information}

Supplementary information is available free of charge at http://jbcs.sbq.org.br as PDF file.

\section{Acknowledgments}

This work was supported by the following Brazilian agencies: CNPq and CAPES.

\section{Author Contributions}

Min-Fu N. Huang, José A. S. Luis, Petrônio F. de Athayde-Filho and José M. Barbosa-Filho conceived and designed the study; Alison P. da Silva, Min-Fu N. Huang, Rafael F. de Oliveira and Helivaldo D. S. Souza performed the experiments; José A. S. Luis, Alison P. da Silva, Marcus T. Scotti and Luciana Scotti performed the in silico study; Juliana C. Rocha and Tatjana K. S. Lima carried out the biological study; José A. S. Luis, Petrônio F. de AthaydeFilho and José M. Barbosa-Filho wrote the paper. 


\section{References}

1. Thompson, A. M.; O’Connor, P. D.; Marshall, A. J.; Yardley, V.; Maes, L.; Gupta, S.; Launay, D.; Braillard, S.; Chatelain, E.; Franzblau, S. G.; J. Med. Chem. 2017, 60, 4212.

2. Savoia, D.; J. Infect. Dev. Countries 2015, 9, 588.

3. Maia, M. S.; Nunes, T. A. L.; Sousa, J. M. S.; Rodrigues, G. C. S.; Monteiro, A. F. M.; Tavares, J. F.; Rodrigues, K. A. F.; Mendonça-Junior, F. J. B.; Scotti, L.; Scotti, M. T.; Molecules 2020, 25, 2281.

4. Cassago, A.; Rodrigues, E. M.; Prieto, E. L.; Gaston, K. W.; Alfonzo, J. D.; Iribar, M. P.; Berry, M. J.; Cruz, A. K.; Thiemann, O. H.; Mol. Biochem. Parasitol. 2006, 149, 128.

5. Noguchi, N.; Arch. Biochem. Biophys. 2016, 595, 109.

6. Souza, C. C.; Barreto, T. D. O.; Silva, S. M.; Pinto, A. W. J.; Figueiredo, M. M.; Rocha, O. G. F.; Cangussú, S. D.; Tafuri, W. L.; Int. J. Exp. Pathol. 2014, 95, 260.

7. Luis, J. A. S.; Souza, H. D. S.; Lira, B. F.; Alves, F. S.; AthaydeFilho, P. F.; Lima, T. K. S.; Rocha, J. C.; Junior, F. J. B. M.; Scotti, L.; Scotti, M. T.; J. Mol. Struct. 2019, 1198, 126872.

8. Luis, J. A. S.; Costa, N. A. C.; Luis, C.; Lira, B. F.; AthaydeFilho, P. F.; Lima, T. K. S.; Rocha, J. C.; Scotti, L.; Scotti, M. T.; Med. Chem. 2020, 16, 39.

9. Lukeš, J.; Mauricio, I. L.; Schönian, G.; Dujardin, J.-C.; Soteriadou, K.; Dedet, J.-P.; Kuhls, K.; Tintaya, K. W. Q.; Jirků, M.; Chocholová, E.; Haralambous, C.; Pratlong, F.; Oborník, M.; Horák, A.; Ayala, F. J.; Miles, M. A.; Proc. Natl. Acad. Sci. U. S. A. 2007, 104, 9375.

10. Ouellette, M.; Drummelsmith, J.; Papadopoulou, B.; Drug Resist. Updates 2004, 7, 257.

11. Menna-Barreto, R. F. S.; Castro, S. L.; BioMed Res. Int. 2014, 2014,14

12. Barbosa, F. A. R.; Canto, R. F. S.; Saba, S.; Rafique, J.; Braga, A. L.; Bioorg. Med. Chem. 2016, 24, 5762.

13. Doroodgar, M.; Delavari, M.; Doroodgar, M.; Abbasi, A.; Taherian, A. A.; Doroodgar, A.; Korean J. Parasitol. 2016, 54, 9.
14. Souza, H. D. S.; de Sousa, R. P. F.; Lira, B. F.; Vilela, R. F.; Borges, N. H. P. B.; de Siqueira-Junior, J. P.; Lima, E. O.; Jardim, J. U. G.; da Silva, G. A. T.; Barbosa-Filho, J. M.; de Athyade-Filho, P. F.; J. Braz. Chem. Soc. 2019, 30, 188.

15. Cruciani, G.; Crivori, P.; Carrupt, P. A.; Testa, B.; J. Mol. Struct. 2000, 503, 17.

16. Knime, 3.5.3; Konstanz Information Miner Copyright, Germany, 2020, available at https://www.knime.com/community/enalosnodes, accessed in October 2020.

17. Akhoundi, M.; Downing, T.; Votýpka, J.; Kuhls, K.; Lukeš, J.; Cannet, A.; Ravel, C.; Marty, P.; Delaunay, P.; Kasbari, M.; Mol. Aspects Med. 2017, 57, 1.

18. Mandal, S.; Moudgil, M.; Mandal, S. K.; Eur. J. Pharmacol. 2009, 625, 90.

19. Lipinski, C. A.; Lombardo, F.; Dominy, B. W.; Feeney, P. J.; Adv. Drug Delivery Rev. 1997, 23, 3.

20. https://www.organic-chemistry.org/prog/peo/, accessed in October 2020.

21. http://www.swissadme.ch/, accessed in October 2020.

22. Zhao, M. Y.; Abraham, M. H.; Le, J.; Hersey, A.; Luscombe, C. N.; Beck, G.; Sherborne, B.; Pharm. Res. 2002, 19, 1446.

23. Lira, B. F.; Athayde-Filho, P. F.; Miller, J.; ARKIVOC 2004, 6 , 22.

24. Klayman, D. L.; Griffin, T. S.; J. Am. Chem. Soc. 1973, 95, 197.

25. Jemal, M.; Rao, S.; Gatz, M.; Whigan, D.; J. Chromatogr. B: Anal. Technol. Biomed. Life Sci. 2003, 795, 273.

26. Rocha, J. C.; Rodrigues, K. A. F.; Néris, P. L. N.; Silva, L. V.; Almeida, F. S.; Lima, V. S.; Peixoto, R. F.; Veras, R. C.; Medeiros, I. A.; Parasitol. Res. 2019, 118, 3067.

27. GraphPad Prism, version 5.0; GraphPad Software Inc., San Diego, USA, 2016.

Submitted: August 4, 2020 Published online: November 11, 2020 